\title{
A new streptomycin-resistance plasmid from Staphylococcus hyicus and its structural relationship to other staphylococcal resistance plasmids
}

\author{
S. SCHWARZ and H. BLOBEL
}

\section{Institut für Bakteriologie und Immunologie der Justus Liebig-Universität, Gießen, FRG}

\begin{abstract}
Summary. A small plasmid of $4.4 \mathrm{~kb}$ encoding resistance to streptomycin $\left(\mathrm{Sm}^{\mathrm{r}}\right)$ was detected in a multiresistant Staphylococcus hyicus culture from a piglet with exudative epidermitis. The plasmid-encoded properties were determined by interspecies protoplast transformation experiments. This plasmid was further characterised by restriction endonuclease analysis and a preliminary restriction map was constructed. The plasmid from $S$. hyicus that conferred streptomycin resistance was designated as pSAI-1. It showed some structural homology with the streptomycin-chloramphenicol resistance plasmid pSK68 from $S$. aureus of human origin. The MIC of streptomycin in resistance mediated by pSAI-1 was about 10 times higher than the MICs in resistance mediated by $\mathrm{Sm}^{\mathrm{r}}$ plasmids from human $S$. aureus strains.
\end{abstract}

\section{Introduction}

Staphylococcus hyicus causes porcine exudative epidermitis, an economically important disease which preferentially strikes suckling piglets. ${ }^{1,2}$ Skin lesions are the predominant symptoms of this infection. However, kidneys, liver, central nervous system and joints may also be affected. Control of this infection has been attempted mainly with antibiotics. ${ }^{2}$ This might have led to the relatively high incidence of antibiotic resistance amongst $S$. hyicus strains. ${ }^{3}$ Recently, we demonstrated that plasmids played an important role in the antibiotic resistance of $S$. hyicus. ${ }^{4}$ The $3 \cdot 95-\mathrm{kb}$ plasmid pSC 2 , mediating chloramphenicol resistance $\left(\mathrm{Cm}^{\mathrm{r}}\right){ }^{5}$ and the $4 \cdot 55-\mathrm{kb}$ plasmid pST 1 , encoding tetracycline resistance $\left(\right.$ Tet $\left.^{\mathrm{r}}\right),{ }^{6}$ both from porcine $S$. hyicus cultures, were isolated and further characterised by restriction endonuclease analysis.

We now report the isolation and characterisation of a small $S$. hyicus plasmid encoding resistance to streptomycin $\left(\mathrm{Sm}^{\mathrm{r}}\right)$. The $\mathrm{Sm}^{\mathrm{r}}$ plasmid was then compared with resistance plasmids of other staphylococcal species isolated from infections of man and animals.

\section{Material and methods}

\section{Bacterial cultures}

A multiresistant $S$. hyicus strain isolated from a piglet

Received 30 Sep. 1989; revised version accepted 10 Jan. 1990. with exudative epidermitis was used. It was identified according to the methods of Schleifer. ${ }^{3}$

\section{Antibiograms}

The antimicrobial resistance patterns of the original $S$ hyicus strain and the pSAI-1 transformants were determined by the agar diffusion method ${ }^{7}$ with the following disks: ampicillin $25 \mu \mathrm{g}$, chloramphenicol $30 \mu \mathrm{g}$, clindamycin $10 \mu \mathrm{g}$, doxycycline $30 \mu \mathrm{g}$, erythromycin $15 \mu \mathrm{g}$, kanamycin $30 \mu \mathrm{g}$, streptomycin $10 \mu \mathrm{g}$, sulphamethoxazole $23.75 \mu \mathrm{g}+$ trimethoprim $1.25 \mu \mathrm{g}$, and tetracycline $30 \mu \mathrm{g}$. The antibiograms were determined after incubation for $18-24 \mathrm{~h}$ at $37^{\circ} \mathrm{C}^{7}$

\section{Plasmid isolation and gel electrophoresis}

Plasmids were isolated by a modification of the alkaline lysis procedure ${ }^{8}$ and subjected to electrophoresis in agarose $0.7-1.5 \% \mathrm{w} / \mathrm{v}$ gels. ${ }^{5}$ After staining the gels with ethidium bromide (Boehringer, Mannheim, FRG) $10 \mu \mathrm{g} /$ $\mathrm{ml}$, plasmid DNA was visualised by exposure to UV light and photographed (film 667; Polaroid, St Albans, Herts).

\section{Plasmid transformation}

Protoplast transformation experiments were performed according to the method of Chang and Cohen ${ }^{8}$ $S$. aureus RN 4220, a derivative of $S$. aureus RN 8325$4,{ }^{9}$ was chosen as the recipient because it was susceptible to all antimicrobial agents tested and did not carry any plasmid. After transformation, protoplasts were inoculated on to DM3 regeneration plates ${ }^{8}$ and grown for 48 $72 \mathrm{~h}$ at $37^{\circ} \mathrm{C}$. Then the cultures were replica-plated on 
Trypticase Soy Agar (TSA; Oxoid) plates containing streptomycin $75 \mu \mathrm{g} / \mathrm{ml}$. Clones growing on these selective TSA-plates were screened for plasmid DNA.

\section{Restriction endonuclease digests}

Plasmid DNA was treated with 5 units each of the restriction endonucleases BamHI, BstEII, CfoI, ClaI, Eco RI, Hpa II, HindIII, HinfI, MboI and TaqI (Boehringer). ${ }^{10}$ The plasmid fragments were analysed in agarose $0 \cdot 7-2 \cdot 0 \mathrm{w} / \mathrm{v}$ gels $^{5}$ or polyacrylamide $7 \cdot 5 \% \mathrm{w} / \mathrm{v}$ gels, ${ }^{11}$ according to their sizes. The sizes of the linearised plasmids and the respective plasmid fragments were estimated on the basis of logarithmic plots against cleaved $\mathrm{pB} 1 / \lambda \mathrm{dv}$ I-DNA. ${ }^{12}$

\section{Determination of MIC of streptomycin}

Single colonies of the original $S$. hyicus culture, a pSAI$1 S$. aureus transformant and the untransformed $S$. aureus RN 4220 were grown overnight in $2 \mathrm{ml}$ of Brain Heart Infusion Broth (BHI; Merck, Darmstadt, FRG) and $50 \mu \mathrm{l}$ (approximately $5 \times 10^{7} \mathrm{cfn}$ ) of each of these cultures were inoculated into $2-\mathrm{ml}$ volumes of $\mathrm{BHI}$ containing serial concentrations of streptomycin $(10-\mathrm{mg} / \mathrm{L}$ steps from 0 to $200 \mathrm{mg} / \mathrm{L} ; 50 \mathrm{mg} / \mathrm{L}$ steps from $200 \mathrm{mg} / \mathrm{L}$ to $2 \mathrm{~g} /$ L) and grown for $18 \mathrm{~h}$ on a rotary shaker. Growth of the staphylococci was determined also by photometric measurements of the turbidity at $\mathrm{OD}_{600}$. The MIC was recorded as the concentration of streptomycin in the first tube in the series that inhibited visible growth. ${ }^{13}$

\section{Results}

The $S$. hyicus strain was resistant to chloramphenicol, clindamycin, erythromycin, streptomycin and tetracycline. It contained four small plasmids up to $4.55 \mathrm{~kb}$. Of these, one had been identified previously to encode resistance to chloramphenicol $\left(\mathrm{Cm}^{r}\right)^{5}$ and another to encode resistance to tetracyclines $\left(\mathrm{Tet}^{\mathrm{T}}\right) .{ }^{6}$ This study focussed on a third plasmid that specified streptomycin resistance $\left(\mathrm{Sm}^{\mathrm{r}}\right)$. This plasmid function was confirmed by interspecific protoplast transformation of the entire plasmid content of the multiresistant $S$. hyicus strain into a streptomycin-sensitive and plasmidfree $S$. aureus recipient strain. The resulting $\mathrm{Sm}^{\mathrm{r}}$ clones carried a small $\mathrm{Sm}^{\mathrm{r}}$ plasmid, which was designated pSAI-1. The pSAI-1 plasmid was further characterised by restriction endonuclease analysis with the enzymes BstEII, CfoI, ClaI, EcoRI, HindIII, HinfI, HpaII, MboI and TaqI. Digests with CfoI, ClaI, EcoRI and HindIII linearised this plasmid (fig. 1, lane 2) and allowed an estimation of its size to be made-c. $4400 \mathrm{bp}$. HpaII cleaved pSAI-1 in two fragments of 2600 and 1800 bp (fig. 1, lane 1), whereas $M b o I$ digests resulted in three

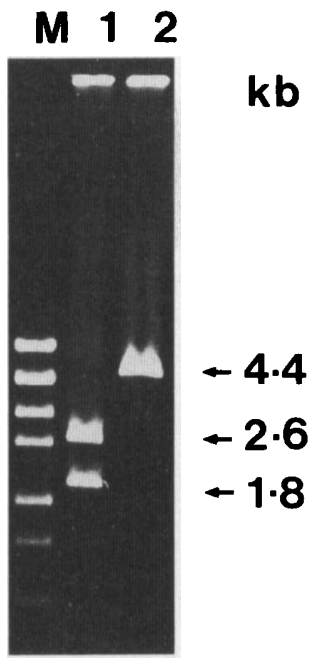

Fig. 1. Agarose gel electrophoresis of pSAI-1 digested with the restriction endonucleases $\mathrm{HpaII}$ (lane 1) and EcoRI (lane 2); M, marker DNA.

fragments of about 1800,1430 , and $1180 \mathrm{bp}$. Digestion with HinfI revealed seven plasmid fragments of $1170,980,810,700,540,160$ and $80 \mathrm{bp}$. In TaqI digests, 10 pSAI-1 fragments of about 1280 , $870,780,430,420,290,140,80,70$ and 60 bp were detected. BstEII did not cleave pSAI-1. The determination of the sizes of the pSAI-1-fragments generated by double restriction endonuclease analyses enabled the localisation of the cleavage sites for the above mentioned restriction enzymes. Thus, a preliminary restriction map was constructed for pSAI-1 (fig. 2). The MIC of streptomycin mediated by pSAI-1 was $c .1000 \mathrm{mg} / \mathrm{L}$. The untransformed $S$. aureus recipient strain did not show visible growth in broth cultures containing streptomycin concentrations $>40 \mathrm{mg} / \mathrm{L}$. Thus, pSAI-1 conferred on the $S$. aureus transformants a 25 -fold increase in streptomycin resistance.

\section{Discussion}

Streptomycin resistance in staphylococci may be encoded either chromosomally or by plasmids. ${ }^{14}$ Chromosomal resistance occurs more frequently, being associated with mutations in the genes encoding ribosomal proteins. ${ }^{14}$ Binding of streptomycin to these altered ribosomal proteins is decreased. Carriage of chromosomal $\mathrm{Sm}^{\mathrm{r}}$ is associated with high MICs (>10 g/L). In contrast, plasmidmediated $\mathrm{Sm}^{\mathrm{r}}$ appears to be of a low-level resistance type with MICs $<100 \mathrm{mg} / \mathrm{L}$. In $S$. aureus, three different classes of $\mathrm{Sm}^{\mathrm{T}}$ plasmids were distinguished (table). The first was represented by large plasmids of $17-51 \mathrm{~kb}$ which encoded not only $\mathrm{Sm}^{\mathrm{r}}$, but also 


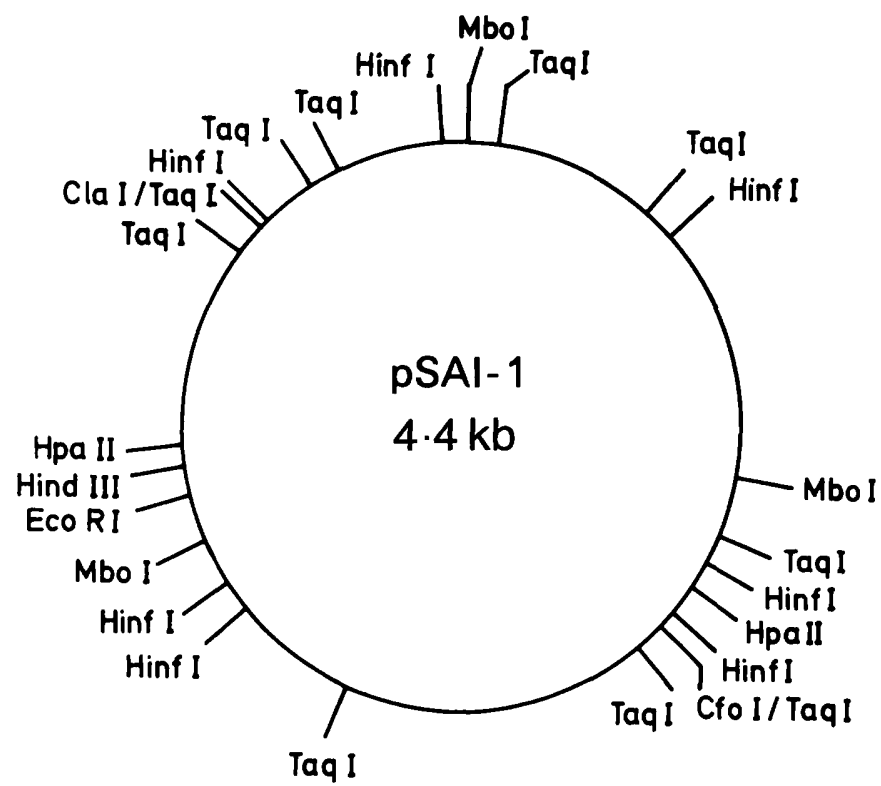

Fig. 2. Circular restriction map of the $\mathrm{Sm}^{\mathrm{r}}$ plasmid $\mathrm{pSAI}-1$ from $S$. hyicus.

resistance to erythromycin, fusidic acid, kanamycin, lincomycin, neomycin or spectinomycin. ${ }^{15,16}$ The second class included small plasmids of 4.6$7.2 \mathrm{~kb}$ which carried the determinants for $\mathrm{Sm}^{\mathrm{r}}$ and $\mathrm{Cm}^{\mathrm{r}} \cdot{ }^{17-19}$ Representatives of the third class of $\mathrm{Sm}^{\mathrm{r}}$ plasmids were small plasmids, $4 \cdot 2-4 \cdot 5 \mathrm{~kb}$, encoding only $\mathrm{Sm}^{\mathrm{r}}$. $^{18-20}$

First attempts to identify $\mathrm{Sm}^{\mathrm{r}}$ plasmids in $S$. hyicus were by Noble et al. ${ }^{21}$ On the basis of curing experiments they considered a plasmid of $2.6 \mathrm{Mda}$ (c. $3.9 \mathrm{~kb}$ ) to be responsible for $\mathrm{Sm}^{\mathrm{r}}$ in eight of 10 streptomycin-resistant $S$. hyicus isolates from pigs. However, no further analysis was reported. The $\mathrm{Sm}^{\mathrm{r}}$ plasmid from $S$. hyicus used in our studies was identified by interspecies protoplast transforma- tion. This experimental approach produced clones that carried only the pSAI- $1 \mathrm{Sm}^{\mathrm{r}}$ plasmid and allowed more detailed analyses. The pSAI-1 plasmid from $S$. hyicus conferred on the transformants $\mathrm{Sm}^{\mathrm{r}}$ with a significantly higher streptomycin MIC than that conferred by the $\mathrm{Sm}^{\mathrm{r}}$ plasmids from $S$. aureus. Plasmid pSAI-1 was also characterised by restriction endonuclease digests. Single digests were used to determine the numbers of cleavage sites for the different restriction enzymes and the sizes of the resultant plasmid fragments. Double digests with restriction endonucleases led to the construction of a restriction map of pSAI-1. Although detailed restriction maps of other staphylococcal $\mathrm{Sm}^{\mathrm{r}}$ plasmids were not available, certain unex-

Table. Representative members of the three classes of staphylococcal $\mathrm{Sm}^{\mathrm{r}}$ plasmids

\begin{tabular}{cl|lcc}
\hline \multirow{2}{*}{ Class } & Plasmid & Resistance markers & Size (kb) & Reference \\
\hline \multirow{2}{*}{ I } & pWA 1 & Sm, Nm, Km, Sp, Fa & $17 \cdot 55$ & 15 \\
& pWG 14 & Sm, Nm, Km, Sp, Em & $45-51$ & 16 \\
II & pSK 68 & Sm, Cm & $4 \cdot 60$ & 17 \\
& pSC 194 & Sm, Cm & $7 \cdot 20$ & 18 \\
& pSA 2100 & Sm, Cm & $7 \cdot 05$ & 19 \\
III & pS 177 & Sm & $4 \cdot 35$ & 20 \\
& pS 194 & Sm & $4 \cdot 5$ & 18 \\
& pSA 0501 & Sm & $4 \cdot 2$ & 19 \\
& pSAI-1 & Sm & $4 \cdot 4$ & This paper \\
\hline
\end{tabular}

$\mathrm{Cm}$, chloramphenicol; Em, erythromycin; $\mathrm{Fa}$, fusidic acid; $\mathrm{Km}$, kanamycin; $\mathrm{Nm}$, neomycin; $\mathrm{Sm}$, streptomycin; $\mathrm{Sp}$, spectinomycin. 
$\mathrm{kb}$
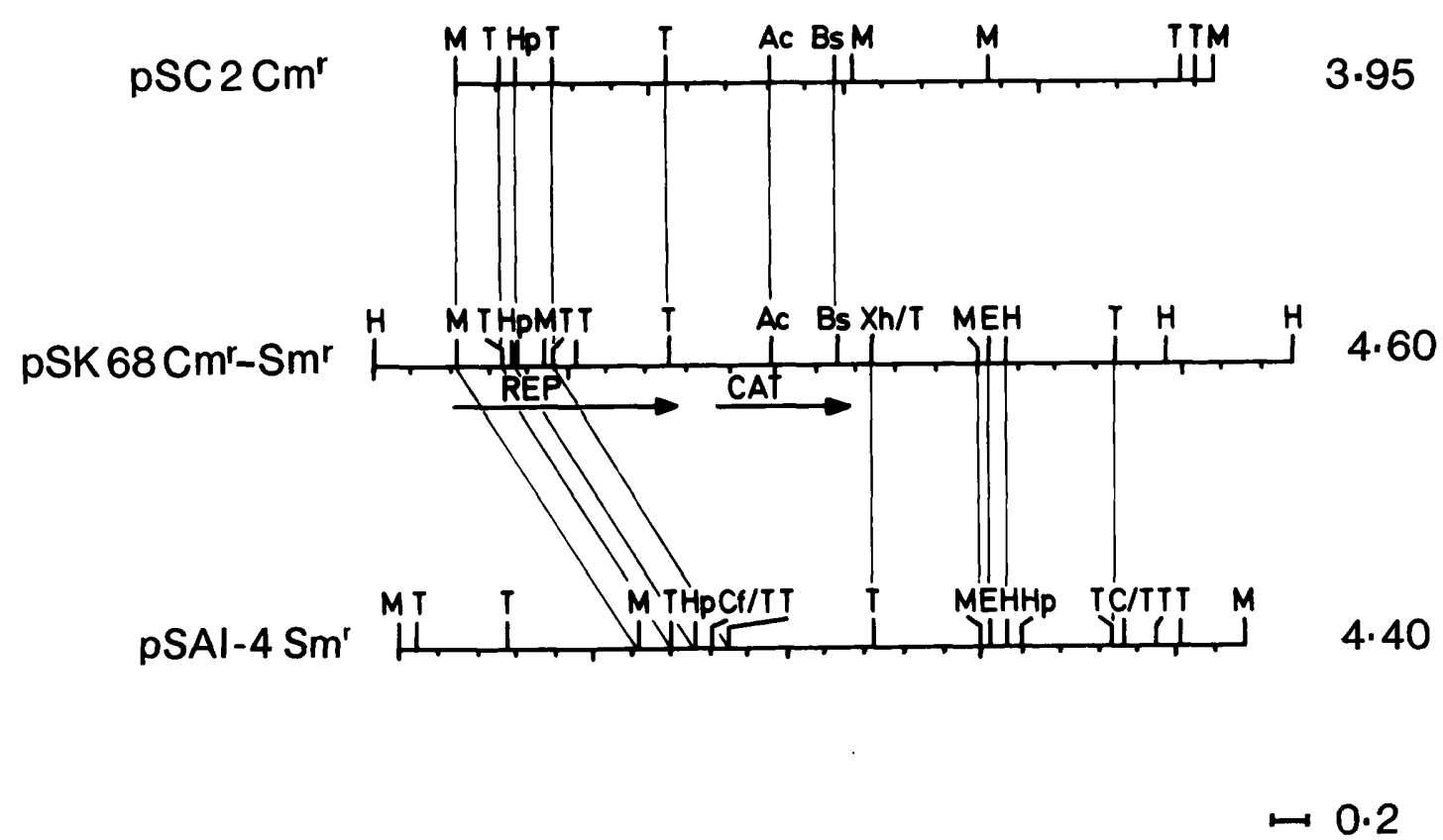

Fig. 3. Restriction maps of the plasmids pSC 2 from porcine $S$. hyicus, pSK 68 from human $S$. aureus and pSAI-1 from porcine $S$. hyicus. Restriction endonuclease cleavage sites are: Ac (AccI), Bs (BstEII), C (ClaI), Cf (CfoI), E (EcoRI), H (HindIII), Hp (HpaII), $\mathrm{M}(\mathrm{Mbol}), \mathrm{T}(\mathrm{TaqI}), \mathrm{Xh}(\mathrm{Xhol})$. The regions encoding replication functions (REP) and chloramphenicol acetyltransferase (CAT) are indicated below the map of pSK 68; the arrows describe the directions of transcription of the REP and CAT genes. For the purpose of better comparison the previously mapped HinfI cleavage sites are deleted in the linear restriction map of pSAI-1; there are no corresponding data concerning $H$ inf I cleavage sites in pSC 2 or pSK 68.

pected similarities were apparent between pSAI-1, pSC $2\left(\text { a } \mathrm{Cm}^{\mathrm{r}} \text { plasmid from } S \text {. hyicus }\right)^{5}$ and the $\mathrm{Cm}^{T}-\mathrm{Sm}^{r}$ plasmid pSK 68 isolated from human $S$. aureus strains in Australia (fig. 3). The pSK 68 plasmid belonged to the class II $\mathrm{Sm}^{\mathrm{r}}$ plasmids and had a replication region (REP) similar to those of pSAI-1 and pSC 2, both from porcine $S$. hyicus strains isolated in Germany. Furthermore, the CAT region in pSK 68 , containing the genetic information for one monomer of the enzyme chloramphenicol acetyltransferase, was also homologous with the respective region in pSC 2 . On the basis of their REP/CAT regions, both plasmids had been classified as belonging to the pC 221 family of $\mathrm{Cm}^{\mathrm{r}}$ plasmids. ${ }^{5,22}$ Plasmids pSAI-1 and pSK 68 also shared a region of about $1200 \mathrm{bp}$, probably involved in streptomycin resistance. In pSAI-1 this region differed from the REP region. In pSK 68 it was obviously involved in neither replication functions nor chloramphenicol resistance. The region, characterised by MboI, EcoRI and HindIII cleavage sites, also corresponded well to those mapped in the $\mathrm{Cm}^{\mathrm{r}}-\mathrm{Sm}^{\mathrm{r}}$ plasmid pSA $2100^{19}$ and in the $\mathrm{Sm}^{\mathrm{r}}$ plasmid pSA $0501 .{ }^{19}$ Moreover, this region was not detectable in the restriction maps of other small plasmids encoding resistance to chloramphenicol, ${ }^{22}$ tetracyclines $^{6,23}$ or macrolides/lincosamides. ${ }^{24,25}$

The restriction maps of plasmids pSAI-1, pSC 2 and pSK 68 suggested that $\mathrm{Cm}^{\mathrm{r}}-\mathrm{Sm}^{\mathrm{r}}$ plasmids, such as pSK 68, were co-integrates between small $\mathrm{Sm}^{\mathrm{r}}$ and small $\mathrm{Cm}^{\mathrm{r}}$ plasmids. ${ }^{14}$ In this connection a recombination site upstream of the REP gene as well as the CAT terminator were found to be involved in recombination events between the $\mathrm{pC}$ $221 \mathrm{Cm}^{\mathrm{r}}$ plasmids and other staphylococcal plasmids. $^{22}$ This recombination site and the CAT terminator possibly also played a role in the formation of $\mathrm{Cm}^{\mathrm{r}}-\mathrm{Sm}^{\mathrm{r}}$ plasmids.

Our findings revealed surprising structural similarities between plasmids encoding the same phenotypic markers in different staphylococcal species from different host species in different parts of the world. These results strongly suggest an exchange of resistance determinants. The transfer of small plasmids between different staphylococcal species by transducing phages has already been demonstrated for the $S$. aureus Tet $^{\mathrm{r}}$ plasmid pT $181 .^{14}$ Structural similarities between small $\mathrm{Cm}^{\mathrm{r}}$ and $\mathrm{Tet}^{\mathrm{r}}$ 
plasmids from porcine $S$. hyicus and their respective counterparts from human $S$. aureus strains have also been shown previously ${ }^{5,6}$ and further suggest that there has been a much higher frequency of plasmid exchange between staphylococci from man

\section{REFERENCES}

1. Gyles CL, Thoen CO (eds) Pathogenesis of bacterial infections in animals, 1st edn. Iowa State University Press. 1986.

2. Rolle MA, Mayr A. Medizinische Mikrobiologie Infektionsund Seuchenlehre für Tierarste, Biologen und Agrarwissenschafter. 5. Aufl. Enke, Verlag, Stuttgart.

3. Schleifer KH. Gram-positive cocci. In: Sneath PHA, Mair NS, Sharpe ME, Holt JG (eds) Bergey's Manual of systematic bacteriology, vol 2. Baltimore, Williams and Wilkins. 1986: 999-1103.

4. Schwarz S, Blobel H. Plasmids and resistance to antimicrobial agents and heavy metals in Staphylococcus hyicus from pigs and cattle. Zentralbl Veterinarmed [B] 1989; 36: 669-673.

5. Schwarz S, Cardoso M, Blobel H. Plasmid-mediated chloramphenicol resistance in Staphylococcus hyicus. $J$ Gen Microbiol 1989; 135 : 3329-3336.

6. Schwarz S, Blobel H. Isolation and restriction enzyme analysis of a tetracycline resistance plasmid from Staphylococcus hyicus. Vet Microbiol (in press).

7. Barry L, Thornsberry C. Susceptibility tests: diffusion test procedure. In: Lenette EH, Ballows A, Hausler WH, Shadomy HJ (eds) Manual of clinical microbiology. 4th edn. Washington DC, American Society for Microbiology. 1985.

8. Chang S, Cohen SN. High frequency transformation of Bacillus subtilis protoplasts by plasmid DNA. Mol Gen Genet 1979; 168: 111-115.

9. Novick R. Properties of cryptic high frequency transducing phage in Staphylococcus aureus. Virology 1967; 33: 155166.

10. Schwarz S, Spies U, Reitz B, Seyfert HM, Lämmler C, Blobel H. Detection and interspecies transformation of a $\beta$-lactamase-encoding plasmid from Pasteurella haemolytica. Zentralbl Bakteriol Mikrobiol Hyg [A] 1989; 270: 462-469.

11. Maniatis T, Fritsch EF, Sambrook J. Molecular cloning: a laboratory manual. Cold Spring Harbour NY, Cold Spring Harbour Laboratory. 1982.

12. Kröger M, Hobom G, Schütte $H$, Mayer $H$. Eight new restriction endonucleases from Herpetosiphon giganteus-divergent evolution in a family of enzymes. Nucleic Acids Res 1984; 12: 3127-3141.

13. Koneman EW, Allen SD, Dowell VR, Sommers HM. Color atlas and textbook of diagnostic microbiology, 2nd edn. Philadelphia, J. B. Lippincott Company. 1983. and animals in vivo than predicted from purely invitro experimental results. ${ }^{26}$

We thank Mrs Marisa Cardoso, Mrs Sabine Grölz-Krug and Mrs Ute Neuschulz for their assistance.

14. Lyon BR, Skurray R. Antimicrobial resistance of Staphylococcus aureus: genetic basis. Microbiol Rev 1987; 51 : 88-134.

15. Lacey RW, Lewis E, Rosdahl VT. Evolution of plasmids in vivo in a strain of Staphylococcus aureus. J Med Microbiol $1974 ; 7: 117-125$.

16. Townsend DE, Ashdown N, Annear DI, Grubb WB. A conjugative plasmid encoding production of a diffusible pigment and resistance to aminoglycosides and macrolides in Staphylococcus aureus. Aust J Exp Biol Med Sci $1985 ; 63$ : 573-586.

17. Gillespie MT, May JW, Skurray RA. Antibiotic resistance in Staphylococcus aureus isolated at an Australian hospital between 1946 and 1981. J Med Microbiol 1985; 19: 137-147.

18. Iordanescu S. Recombinant plasmid obtained from two different, compatible staphylococcal plasmids. $J$ Bacteriol $1975 ; 124$ : 597-601.

19. Gryczan TJ, Contente S, Dubnau D. Characterization of Staphylococcus aureus plasmids introduced by transformation into Bacillus subtilis. J Bacteriol 1978; 134: 318 329.

20. Novick RP, Sanchez-Rivas C, Gruss A, Edelman I. Involvement of the cell envelope in plasmid maintenance: plasmid curing during the regeneration of protoplasts. Plasmid 1980; 3: 348-358.

21. Noble WC, Rahman MJ, Lloyd DH. Plasmids in Staphylococcus hyicus. J Appl Bacteriol 1988; 64: 145-149.

22. Gillespie MY, Skurray RA. Structural relationships among chloramphenicol-resistance plasmids of Staphylococcus aureus. FEMS Microbiol Lett 1988; 51 : 205-210.

23. Khan SA, Novick RP. Complete nucleotide sequence of pT 181 , a tetracycline-resistance plasmid from Staphylococcus aureus. Plasmid 1983; 10 : 251-259.

24. Horinouchi S, Weisblum B. Post-transcriptional modification of mRNA conformation : mechanism that regulates erythromycin-induced resistance. Proc Natl Acad Sci 1980; 77: 7079-7083.

25. Lampson BC, Parisi JT. Nucleotide sequence of the constitutive macrolide-lincosamide-streptogramin B resistance plasmid pNE131 from Staphylococcus epidermidis and homologies with Staphylococcus aureus plasmids pE194 and pSN 2. J Bacteriol 1986; 167 : 888-892.

26. Lacey $\mathrm{RW}$. Rarity of gene transfer between animal and human isolates of Staphylococcus aureus in vitro. $J$ Gen Microbiol 1980; 119: 437-442. 